\title{
Magnetic Solid Phase Extraction of Lead, Cadmium, and Cobalt on Magnetic Carboxyl-Modified Nanodiamonds (MCNDs) from Natural Water Samples and Their Determination by Flame Atomic Absorption Spectrometry
}

\author{
Mansoor Khan ${ }^{a, b, c}$ and Mustafa Soylak ${ }^{a, *}$ \\ ${ }^{a}$ Erciyes University, Faculty of Sciences, Department of Chemistry, 38039 Kayseri, Turkey \\ ${ }^{b}$ Institute of Chemical Sciences, University of Peshawar, Peshawar, Pakistan \\ ${ }^{c}$ Department of Chemistry, Kohat University of Science and Technology, Khyberpakhtunkhwa, Pakistan
}

\section{INTRODUCTION}

The excessive discharge of $\mathrm{Pb}$, $\mathrm{Cd}$, and $\mathrm{Co}$ into the natural water body from many industrial, natural, and anthropogenic sources causes serious environmental pollution. These heavy metals are toxic to various organs of humans and animals such as the central nervous, reproductive, immune, and gastro-intestinal systems even at trace levels (1-4). Therefore, the determination of these heavy metals at trace and ultra-trace levels is of immense interest. The analytical technique of flame and graphite furnace atomic absorption spectrometry (FAAS/ GFAAS), inductively coupled plasma optical emission spectrometry (ICP-OES), inductively coupled plasma mass spectrometry (ICPMS), including electroanalytical techniques have been employed excessively in the recent past (5) However, due to the low levels of these heavy metals in the environment, the direct determination even by using sensitive analytical techniques is not possible. A proper pre-concentration step is required prior to their determination by flame atomic absorption spectrometry (FAAS) to increase the detection limit in environmental samples (6-8).

The analytical extraction and preconcentration methods of dispersive liquid-liquid extraction (DLLE) (9), head space liquid phase extraction (HSLPE) (10), cloud

\footnotetext{
* Corresponding author.

E-mail: soylak@erciyes.edu.tr

Fax: +903524374933
}

\begin{abstract}
A magnetic carboxyl-modified nanodiamond (MCND) was used for the magnetic solid phase extraction of $\mathrm{Pb}(\mathrm{II}), \mathrm{Cd}(\mathrm{II})$, and $\mathrm{Co}$ (II) prior to their quantification by flame atomic absorption spectrometry. The external magnetic field was used to separate the magnetic solid phase from the analyte solution in order to avoid sample loss during filtration and centrifugation. Various factors affecting the extraction efficiency of the adsorbent such as solution $\mathrm{pH}$, adsorbent dose, sample volume, temperature, matrix effect, and desorption condition were optimized. The analytical parameters of the limit of detection $(\mathrm{Pb}$ : $0.99 \mu \mathrm{g} \mathrm{L}{ }^{-1}, \mathrm{Co}: 1.73 \mu \mathrm{g} \mathrm{L}{ }^{-1}, \mathrm{Cd}$ : $0.15 \mu \mathrm{g} \mathrm{L}^{-1}$ ), preconcentration factor of 20 for the analytes, and percent relative standard deviation $(\mathrm{Pb}: 0.5 \%, \mathrm{Cd}: 0.6 \%, \mathrm{Co}$ : $0.6 \%$ ) were calculated under optimized experimental condition. The kinetic data show that this adsorption process follows pseudo-second order kinetics. The thermodynamic data show that this adsorption process was feasible and exothermic in nature. The method was validated by applying the method to certified reference materials TMDA 64.2 and SPS-WW2 and natural water samples with satisfactory recovery results.
\end{abstract}

point extraction (CPE) (11), in situ solvent formation extraction (ISFE) (12), ultrasound ionic liquid-based dispersive liquid extraction (UILBDLE) (13), co-precipitation (14), and switchable solvent-based liquid extraction (SSLE) (15) have been employed over the last few years. However, high amounts of toxic organic reagents discharged into the waste make these techniques environmentally unfriendly and expensive. These limitations can be eliminated by using solid phase extraction (SPE), which is a promising technique for the removal of heavy metals from environmental samples (16-18).

Magnetic nanoparticles and magnetically modified materials such as carbon nanotubes (19), magnetic nanoparticles $(20,21)$, magnetic graphene (22), magnetically impregnated biosorbents (23), and mesoporous materials have been used as SPE adsorbents (24). Due to the smaller particle size $(1 \mathrm{~nm}$ to $200 \mathrm{~nm}$ ) (25), large surface area, and magnetic property, the magnetic nanoparticle can be used as an effective SPE adsorbent for heavy metals in water samples and is an excellent method for the preconcentration of heavy metals from aqueous solutions $(26,27)$.

Due to the unique properties of hardness, thermal conductivity, and optical transparency over a wide spectral range, diamonds have become a focus of interest and are used for electronic and electrochemical devices, sensors, protective coatings, and optical windows. Diamond nanowires and nanopillers for photonic devices are the recent application of single crystalline nanodiamonds. A new kind of carbon material called nanodiamond was found to have properties close to diamonds and is considered a key material in quantum engineer- 
ing, has widespread biological and electronic application, as well as for composite materials $(28,29)$. Due to their high surface reactivity, nanodiamonds can be used as an excellent adsorbent for heavy metals determination from environmental water samples.

The aim of the present work was to use magnetic carboxyl-modified nanodiamonds (MCNDs) as adsorbents for $\mathrm{Pb}, \mathrm{Cd}$, and Co separationpreconcentration and determination in various water samples. Adsorption kinetics, thermodynamics, and equilibrium of constants were also studied.

\section{EXPERIMENTAL}

\section{Instrumentation}

A flame atomic absorption spectrometer Model A300 (PerkinElmer, Inc., Shelton, CT, USA) with an airacetylene flame on a $10 \mathrm{~cm}$ long slot burner head was used for the metal determinations. A hollow cathode lamp was the excitation source. A continuous injection system was used to inject $100 \mu \mathrm{L}$ of the eluent to the nebulizer of the FAAS. All instrumental settings used were as recommended by the manufacturer and are listed in Table I.

The measurements were performed with the continuous aspiration mode of the FAAS. The $\mathrm{pH}$ of the solution was measured with a Nel-pH-900 meter with a glass electrode (Ankara, Turkey). The solid phase was separated by using a Nd magnet. A vortex mixer (Wiggen

\section{TABLE I}

Instrumental and Operating Conditions for $\mathrm{Cd}, \mathrm{Pb}$, and $\mathrm{Co}$

\begin{tabular}{cccc}
\hline $\begin{array}{c}\text { Ele- } \\
\text { ments }\end{array}$ & $\begin{array}{c}\text { Wave } \\
\text { length } \\
\text { (nm) }\end{array}$ & $\begin{array}{c}\text { Slit } \\
\text { Width } \\
\text { (nm) }\end{array}$ & $\begin{array}{c}\text { Lamp } \\
\text { Current } \\
\text { (mA) }\end{array}$ \\
\hline $\mathrm{Cd}$ & 228.8 & 0.7 & 4 \\
$\mathrm{~Pb}$ & 283.3 & 0.7 & 10 \\
$\mathrm{Co}$ & 240.7 & 0.7 & 23 \\
\hline
\end{tabular}

Hauser, Malaysia) was used for the homogenous mixing of the solutions.

\section{Chemicals and Reagents}

High purity analytical grade reagents were used for preparation of the $\mathrm{Pb}, \mathrm{Cd}$, and Co stock solutions (E. Merck Co., Germany). In order to prepare the magnetic iron oxide nanoparticle $\left(\mathrm{Fe}_{3} \mathrm{O}_{4}\right)$; ferric chloride hexahydrate $\left(\mathrm{FeCl}_{3} \cdot 6 \mathrm{H}_{2} \mathrm{O}\right)$ and ferrous sulphateheptahydrate $\left(\mathrm{FeSO}_{4} \cdot 7 \mathrm{H}_{2} \mathrm{O}\right)$ salts were used $(\mathrm{E}$. Merck Co., Germany). Ammonia solution (35\%), hydrochloric acid (37\%), acetone, and ethanol were purchased from Riedel-deHaen (Sleeze, Germany) and SigmaAldrich (St. Louis, MO, USA).

Nanodiamonds (Sigma-Aldrich No: 636428-1G) were purchased form Sigma Aldrich (St. Louis, MO, USA). Synthesis and characterization of the magnetic carboxyl-modified nanodiamonds (MCNDs) were performed according to the literature (30).

To obtain the appropriate $\mathrm{pH}$ of the sample solutions, different combinations of acids and salts were used: Phosphate buffer solution ( $\mathrm{pH} 2-4$, sodium dihydrogen phosphate/phosphoric acid), acetate buffer solution ( $\mathrm{pH}$ 5.0-7.0 acetic acid and ammonium acetate), ammonia buffer solution ( $\mathrm{pH}$ 8.0, ammonia/ammonium chloride), and phosphate buffer solution $(\mathrm{pH}$ 9.0 and $\mathrm{pH} 10$ sodium phosphate).

\section{Batch Adsorption Studies}

A 10-mL sample solution containing $8 \mu \mathrm{g} \mathrm{Pb}, 4 \mu \mathrm{g} \mathrm{Co}$, and $2 \mu \mathrm{g} \mathrm{Cd}$ was taken into a $50-\mathrm{mL}$ centrifuge tube at $\mathrm{pH}$ 7. The solution was then added to another tube having $0.1 \mathrm{~g}$ of magnetic carboxyl-modified nanodiamonds (MCNDs). The adsorption was allowed for 4 minutes using a vortex revolution speed of $40 \times 100$ per minute. After complete adsorption, the solid phase was separated by using the external magnetic field, and the liquid phase was carefully decanted to waste. For desorption, $2 \mathrm{~mL}$ of $2 \mathrm{M} \mathrm{HCl}$ in acetone was added to the tube with the adsorbent, again subjected to vortex revolution for 4 minutes, and separated from the liquid phase using the external magnetic field. A $1.9 \mathrm{~mL}$ amount of acetone was separated by using a boiling waterbath for half an hour. An amount of $100 \mu \mathrm{L}$ of eluent was injected into the nebulizer of the FAAS by using the micro-injection system for measurement of the analytes. The schematic of the presented procedure is summarized in Figure 1.

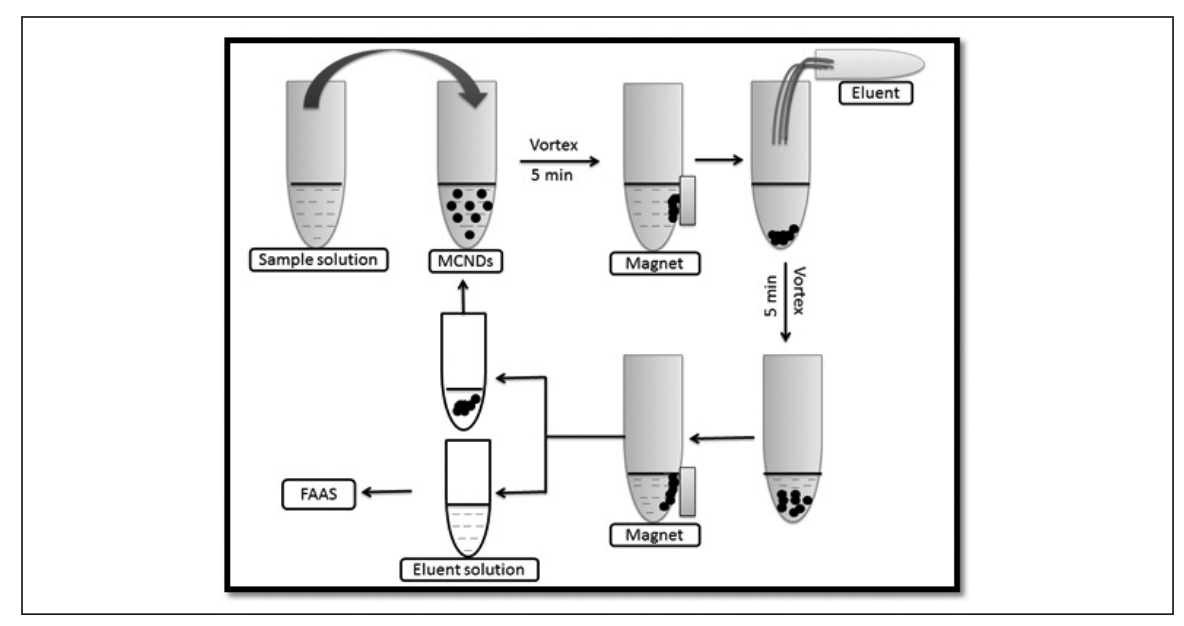

Fig. 1. Schematic presentation of present procedure. 
The adsorption capacity (q) was calculated by using the following equation:

$$
q=\left(C_{i}-C_{f}\right) m / v
$$

where $C_{i}$ is the initial concentration of the analyte, $\mathrm{C}_{\mathrm{f}}$ is the final concentration, $m$ is the amount of adsorbent, and $\mathrm{V}$ is the sample volume.

\section{Application}

Two certified reference materials of TMDA 64.2 Environmental Water (The National Water Research Institute, Environment Canada, Burlington, Canada) and SPS-WW2 Wastewater (Spectrapure Standards AS, Oslo, Norway) were used for the trace metal determination of $\mathrm{Pb}, \mathrm{Cd}$, and Co. Three environmental water samples (underground water, seawater, and wastewater obtained from various cities in Turkey) were used for validation of the method. The certified reference materials were used directly without further purification, while the environmental water samples were passed through a cellulose membrane filter having $0.45 \mu \mathrm{m}$ pore size (Millipore Corporation, USA) prior to use to remove the waste particles. Then the procedure given above (see Batch Adsorption Studies) was applied.

\section{RESULTS AND DISCUSSION}

The analytical variables of $\mathrm{pH}$, adsorbent dose, vortex time, sample volume, matrix effect, type, and volume of the eluent were optimized for the quantitative percent recovery of $\mathrm{Pb}$ (II), $\mathrm{Co}(\mathrm{II})$, and Cd(II) on magnetic carboxyl-modified nanodiamonds (MCNDs). The following equation was used to calculate the percent recovery values (31):

(Eq. 2)

$\operatorname{Recovery}(\%)=\left(\mathrm{w}_{\mathrm{o}} / \mathrm{w}_{\mathrm{f}}\right) \times 100$

where $\mathrm{w}_{\mathrm{o}}(\mu \mathrm{g})$ and $\mathrm{w}_{\mathrm{f}}(\mu \mathrm{g})$ are the amount of analyte in the final and the sample solutions, respectively.

\section{Effect of $\mathbf{p H}$}

The $\mathrm{pH}$ of a solution greatly influences the surface charge of the adsorbent and the hydronium $\left(\mathrm{H}_{3} \mathrm{O}^{+}\right)$ion concentration in the sample solution greatly affects the adsorption efficiency of the adsorbent (32-36). Therefore, for a suitable $\mathrm{pH}$, adsorption studies of $\mathrm{Pb}$ (II), Co(II), and Cd(II) on magnetic carboxyl-modified nanodiamonds (MCNDs) were carried out at a different $\mathrm{pH}$ ranging from 3.0 to 9.0 (see Figure 2). The quantitative recoveries of the analyte ions were obtained at $\mathrm{pH} 7.0$ and 7.5.

\section{Atomic Apectroscopy \\ Vol. 39(2), March/April 2018}

Thus, pH 7.0 was used for all optimization studies.

\section{Effect of Adsorbent Dose}

The smallest amount of adsorbent required to obtain quantitative percent recoveries of the analyte ions was determined by using different adsorbent doses (20 $\mathrm{mg}$ to $140 \mathrm{mg}$ ). Figure 3 shows that a 100-mg amount of magnetic carboxyl-modified nanodiamonds (MCNDs) was sufficient to obtain quantitative percent recoveries of $\mathrm{Pb}, \mathrm{Cd}$, and $\mathrm{Co}$, and was used in further optimization studies.

\section{Effect of Sample Volume}

The highest preconcentration factor of the method can be calculated after determining the highest sample volume to which the method is successfully applicable. For this purpose, the proposed solid phase extraction method was applied to sample volumes ranging from $5 \mathrm{~mL}$ to $50 \mathrm{~mL}$. Figure 4 shows that $40 \mathrm{~mL}$ is the highest volume at which quantitative percent recoveries of the analyte metals are achieved. Therefore, a preconcentration factor of 20 was achieved using a 40-mL sample volume and $2 \mathrm{~mL}$ of final volume.

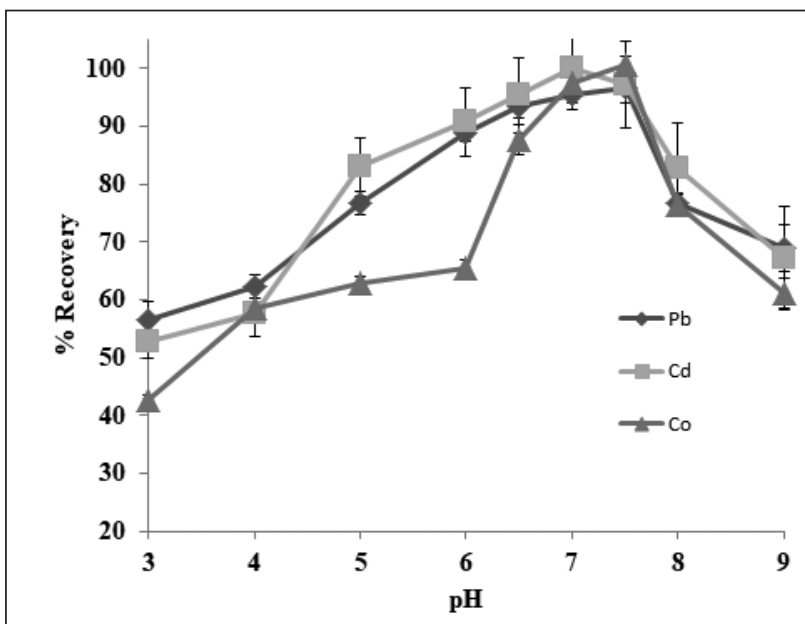

(F)ig. 2. Effect of pH on recovery (\%) of $\mathrm{Pb}(\mathrm{II}), \mathrm{Cd}(\mathrm{II})$ and Co(II) using MCNDs as adsorbent.

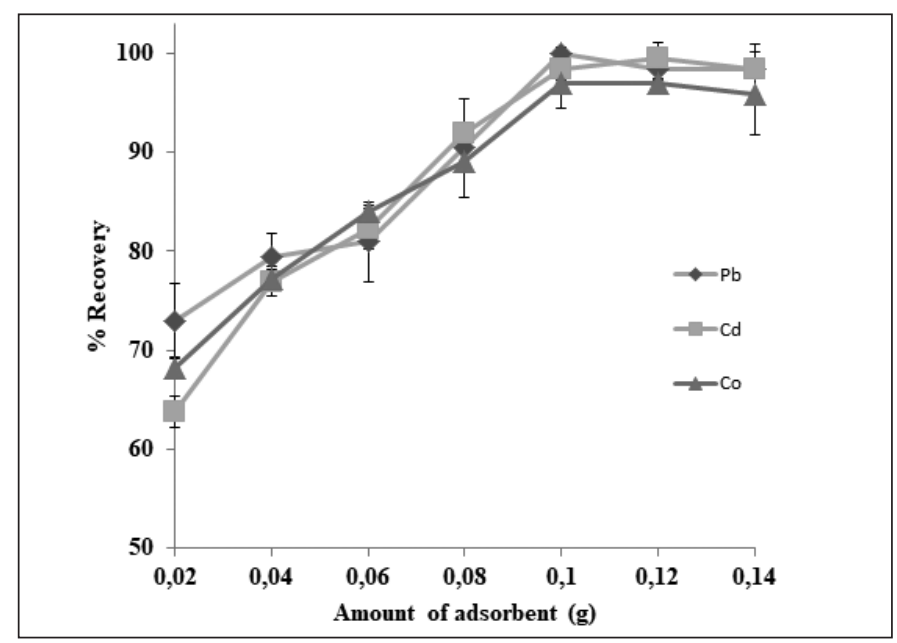

Fig. 3. Effect of adsorbent dose on recovery (\%) of Pb(II), Cd(II) and Co(II) using MCNDs as adsorbent. 


\section{Desorption Studies}

The selection of type, concentration, and volume of the best eluent is of enormous importance in solid phase extraction and preconcentration studies. Various types of eluting agents with different concentrations were used for desorption of $\mathrm{Pb}$ (II), $\mathrm{Cd}(\mathrm{II})$, and $\mathrm{Co}$ (II) from the surface magnetic carboxyl-modified nanodiamonds (MCNDs). Table II shows that $2 \mathrm{M} \mathrm{HCl}$ in acetone is the best eluting agent for desorption of the analytes from the surface of magnetic carboxyl-modified nanodiamonds (MCNDs).

To investigate the smallest volume of eluent, different volumes (1 to $6 \mathrm{~mL}$ ) of $2 \mathrm{M} \mathrm{HCl}$ in acetone were used. Figure 5 shows that $2 \mathrm{~mL}$ of eluent was enough for the complete desorption of the metal ions from the surface of the adsorbent.

\section{Matrix Effect}

The interfering influences of the cations of the IA and IIA group elements and some transition elements, as well as some anions on the instrumental detection of metals at trace levels are known as matrix effects (37-42). The effects of different interfering ions on the percent recovery of analyte ions were investigated and the results are listed in Table III. No significant interferences were obtained even at high concentrations of the interfering ions. It can, therefore, be concluded that the adsorption of $\mathrm{Pb}(\mathrm{II}), \mathrm{Cd}(\mathrm{II})$, and $\mathrm{Co}$ (II) on magnetic carboxyl-modified nanodiamonds (MCNDs) is highly selective.

\section{Kinetic Studies}

Kinetic data can be explained by using various kinetic models such as pseudo-first-order, pseudo-second-order kinetics, and intraparticle diffusion models for the adsorption of $\mathrm{Pb}(\mathrm{II}), \mathrm{Cd}(\mathrm{II})$, and $\mathrm{Co}$ (II) on magnetic carboxyl-modified nanodiamonds (MCNDs). For pseudo-firstorder kinetics, the following expression was used (43):

$$
\log \left(\mathrm{q}_{\mathrm{e}}-\mathrm{q}_{\mathrm{t}}\right)=\log \mathrm{q}_{\mathrm{e}}-\frac{\mathrm{k}_{1}}{2.303} \mathrm{t}
$$

The values of adsorption at equilibrium $\mathrm{q}_{\mathrm{e}}$ and $\mathrm{k}_{1}$ pseudo-first-order constant were calculated from intercept and slope, respectively, and the values are listed in Table IV. The smaller coefficient values

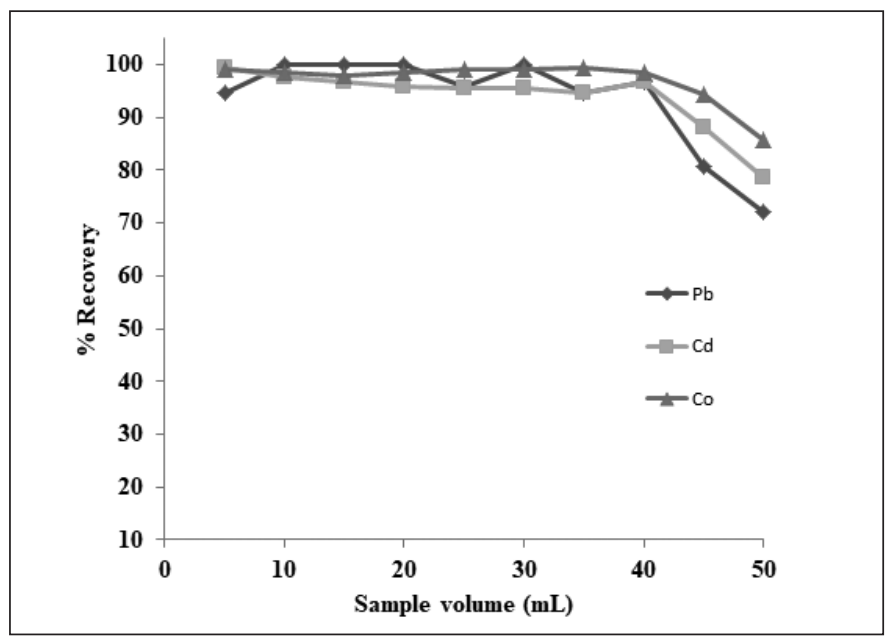

Fig. 4. Effect of sample volume on recovery (\%) of $\mathrm{Pb}(\mathrm{II})$, Cd(II) and Co(II) using MCNDs as adsorbent.
TABLE II

Effect of Type and Concentration of Eluent on (\%) Recovery of $\mathrm{Pb}(\mathrm{II}), \mathrm{Cd}(\mathrm{II})$, and Co(II) Magnetic Carboxyl Modified Nanodiamonds (MCNDs) $(\mathrm{N}=3)$

\begin{tabular}{lccc}
\hline & \multicolumn{3}{c}{ Recovery(\%) } \\
Eluent Type & $\mathrm{Pb}$ & $\mathrm{Cd}$ & $\mathrm{Co}$ \\
\hline $1 \mathrm{M} \mathrm{HCl}$ & $83 \pm 2^{\mathrm{a}}$ & $69 \pm 4$ & $78 \pm 2$ \\
$2 \mathrm{M} \mathrm{HCl}$ & $84 \pm 1$ & $84 \pm 2$ & $84 \pm 2$ \\
$3 \mathrm{M} \mathrm{HCl}$ & $89 \pm 1$ & $92 \pm 2$ & $89 \pm 2$ \\
$1 \mathrm{HNO}_{3}$ & $68 \pm 2$ & $62 \pm 2$ & $61 \pm 3$ \\
$2 \mathrm{HNO}_{3}$ & $80 \pm 1$ & $85 \pm 5$ & $73 \pm 4$ \\
$3 \mathrm{HNO}_{3}$ & $89 \pm 3$ & $91 \pm 4$ & $75 \pm 1$ \\
$1 \mathrm{M} \mathrm{HCl}^{\text {in Acetone }}$ & $99 \pm 4$ & $95 \pm 3$ & $93 \pm 2$ \\
$2 \mathrm{M} \mathrm{HCl}$ in Acetone & $102 \pm 2$ & $99 \pm 3$ & $97 \pm 3$ \\
$3 \mathrm{M} \mathrm{HCl}$ in Acetone & $104 \pm 4$ & $100 \pm 3$ & $96 \pm 4$ \\
\hline
\end{tabular}

${ }^{\mathrm{a}}$ Mean \pm standard deviation.

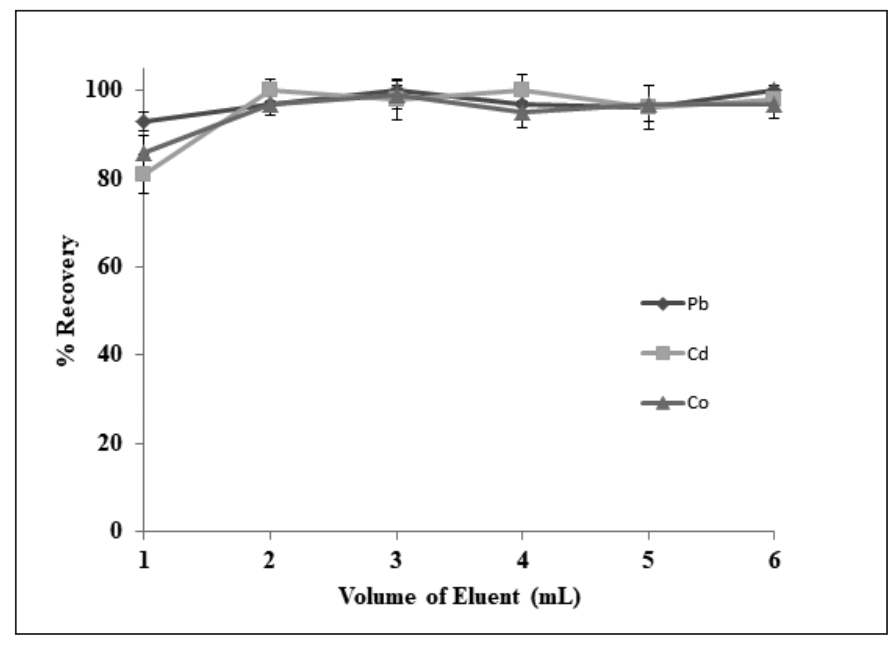

Fig. 5. Effect of eluent volume on recovery (\%) of $\mathrm{Pb}(\mathrm{II}), \mathrm{Cd}(\mathrm{II})$ and Co(II) using MCNDs as adsorbent. 
and the difference between experimental adsorption capacities and calculated adsorption capacities from pseudo-first-kinetics confirm that this adsorption study follows some other kinetic model.
The rate limiting step in chemisorption can be calculated by using the pseudo-first-order kinetics model which can be expressed by using the following equation (44):

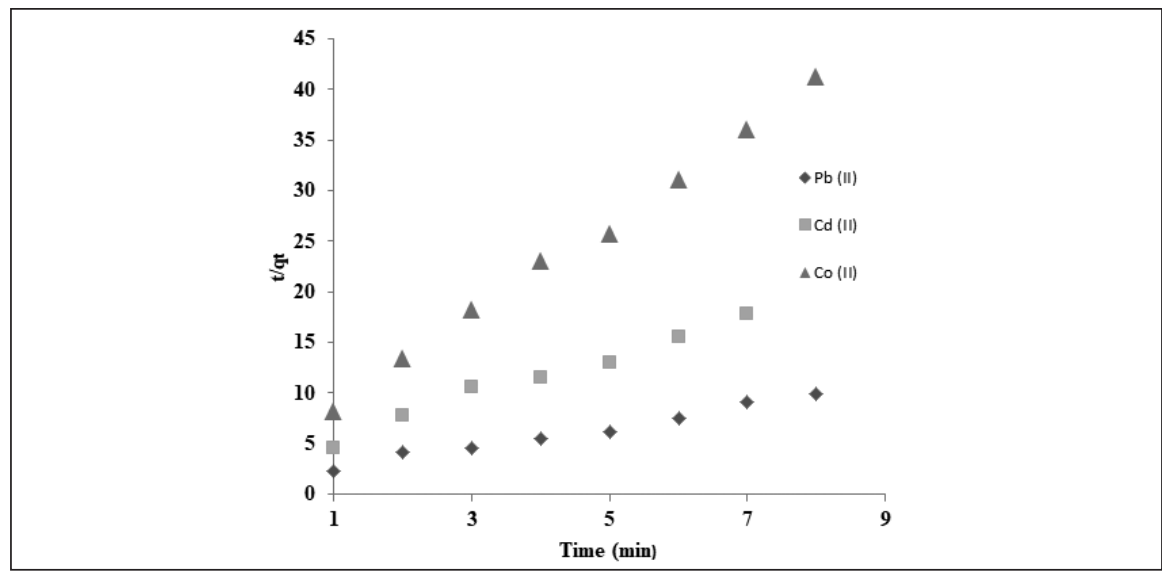

Fig. 6. Pseudo-second order kinetics.

TABLE III

Effect of Coexisting Ions on (\%) Recovery of $\mathrm{Pb}(\mathrm{II}), \mathrm{Cd}(\mathrm{II})$, and $\mathrm{Co}$ (II) Using (MCNDs), pH: 7, Adsorbent: 0.1 g, Sample Solution: $10 \mathrm{~mL}(\mathrm{~N}=3)$

\begin{tabular}{lcrrrr}
\hline $\begin{array}{l}\text { Interfering } \\
\text { Ions }\end{array}$ & Added as & $\begin{array}{c}\text { Concentration } \\
\left(\mathrm{mg} \mathrm{L}^{-1}\right)\end{array}$ & $\mathrm{Pb}(\mathrm{II})$ & $\mathrm{Cd}(\mathrm{II})$ & $\mathrm{Co}(\mathrm{II})$ \\
\hline $\mathrm{Na}^{+}$ & $\mathrm{NaCl}$ & 5000 & $95 \pm 5^{\mathrm{a}}$ & $99 \pm 3$ & $99 \pm 4$ \\
$\mathrm{~K}^{+}$ & $\mathrm{KCl}$ & 5000 & $95 \pm 6$ & $95 \pm 2$ & $94 \pm 6$ \\
$\mathrm{Ca}^{++}$ & $\mathrm{Ca}\left(\mathrm{NO}_{3}\right)_{2} \cdot 4 \mathrm{H}_{2} \mathrm{O}$ & 500 & $98 \pm 4$ & $100 \pm 4$ & $95 \pm 4$ \\
$\mathrm{Mg}^{++}$ & $\mathrm{Mg}\left(\mathrm{NO}_{3}\right)_{2} \cdot 6 \mathrm{H}_{2} \mathrm{O}$ & 500 & $96 \pm 4$ & $93 \pm 5$ & $92 \pm 2$ \\
$\mathrm{Al}^{+++}$ & $\mathrm{Al}\left(\mathrm{NO}_{3}\right)_{3} \cdot 7 \mathrm{H}_{2} \mathrm{O}$ & 100 & $94 \pm 5$ & $95 \pm 7$ & $102 \pm 1$ \\
$\mathrm{Zn}^{++}$ & $\mathrm{Zn}\left(\mathrm{NO}_{3}\right)_{2} \cdot 6 \mathrm{H}_{2} \mathrm{O}$ & 100 & $100 \pm 3$ & $98 \pm 1$ & $98 \pm 5$ \\
$\mathrm{Cu}^{++}$ & $\mathrm{Cu}\left(\mathrm{NO}_{3}\right)_{2} \cdot 6 \mathrm{H}_{2} \mathrm{O}$ & 50 & $96 \pm 2$ & $93 \pm 4$ & $99 \pm 3$ \\
$\mathrm{Ni}^{++}$ & $\mathrm{Ni}\left(\mathrm{NO}_{3}\right)_{2} \cdot 6 \mathrm{H}_{2} \mathrm{O}$ & 100 & $96 \pm 3$ & $97 \pm 7$ & $97 \pm 3$ \\
$\mathrm{Mn}^{++}$ & $\mathrm{Mn}\left(\mathrm{NO}_{3}\right)_{2} \cdot 6 \mathrm{H}_{2} \mathrm{O}$ & 50 & $95 \pm 4$ & $93 \pm 5$ & $94 \pm 4$ \\
$\mathrm{SO}_{4}^{-}$ & $\mathrm{Na}_{2} \mathrm{SO}_{4}$ & 500 & $96 \pm 2$ & $95 \pm 3$ & $99 \pm 2$ \\
$\mathrm{CO}_{3}^{-}$ & $\mathrm{Na}_{2} \mathrm{CO}_{3}$ & 500 & $94 \pm 6$ & $95 \pm 2$ & $101 \pm 2$ \\
$\mathrm{~F}^{-}$ & $\mathrm{NaF}^{-}$ & 100 & $100 \pm 5$ & $97 \pm 2$ & $98 \pm 8$ \\
\hline
\end{tabular}

${ }^{a}$ Mean \pm standard deviation.

\section{Atomic Apectroscopy \\ Vol. 39(2), March/April 2018}

$$
\left.\mathrm{t} / \mathrm{q}_{\mathrm{t}}=\mathrm{t} / \mathrm{q}_{\mathrm{e}}+1 / \mathrm{k}_{2} \mathrm{q}_{\mathrm{e}} 2 \quad \text { (Eq. } 4\right)
$$

The value of equilibrium adsorption capacity $\mathrm{q}_{\mathrm{e}}$ and rate constant for pseudo-second-order kinetics $\mathrm{k}_{2}$ were calculated from slope and intercept and intercept of the linear plot, represented by Figure 6 . The close agreement was found between the calculated adsorption capacities and high correlation coefficient $\left(\mathrm{R}^{2}\right)$ values. The calculated adsorption capacities confirm that these adsorption studies follow pseudo-second-order kinetics (Table IV).

The following equation was used in order evaluate intraparticle diffusion model (23):

$$
\mathrm{q}_{\mathrm{t}}=\mathrm{k}_{\mathrm{int}} \mathrm{t}^{1 / 2}+\mathrm{C}
$$

The value of boundary layer thickness $\mathrm{C}$ and intraparticle diffusion rate constant $\mathrm{k}_{\text {int }}\left(\mathrm{mg} \mathrm{g}^{-1}\right.$ $\min ^{-1 / 2}$ ) were calculated directly from intercept and slope of the intraparticle diffusion model and are given in Table IV. The plot of $\mathrm{q}_{\mathrm{t}}\left(\mathrm{mg} \mathrm{g}^{-1}\right)$ and $\mathrm{t}^{1 / 2}$ shows that this adsorption process is a three-step process, mainly due to surface diffusion and intraparticle diffusion, while the positive value of $\mathrm{C}$ is mainly due to the boundary layer diffusion. The multistep adsorption process confirmed some other adsorption mechanism, such as ion exchange may control the rate of adsorption.

\section{Thermodynamic Studies}

In order to determine the values of enthalpy $\left(\Delta \mathrm{H}^{\circ}\right)$, Gibbs-free energy $\left(\Delta G^{0}\right)$, and entropy $\left(\Delta S^{o}\right)$,

TABLE IV

\begin{tabular}{|c|c|c|c|c|c|c|c|c|c|c|}
\hline \multirow[t]{2}{*}{$\begin{array}{l}\text { Metal } \\
\text { Ion }\end{array}$} & \multirow{2}{*}{$\begin{array}{c}\text { Experimental } \\
\mathrm{q}_{\mathrm{e} \mu \mathrm{gg}}{ }^{-1}\end{array}$} & \multicolumn{3}{|c|}{ Pseudo First Order } & \multicolumn{3}{|c|}{$\begin{array}{l}\text { Kinetic Models } \\
\text { Pseudo Second Order }\end{array}$} & \multicolumn{3}{|c|}{ Intra-particle Diffusion } \\
\hline & & $\mathrm{K}_{1} \min ^{-1}$ & $\mathrm{q}_{\mathrm{e} \mu \mathrm{g}^{-1}}$ & $\mathrm{R}^{2}$ & $\mathrm{~K}_{2 \min ^{-1}}$ & $\mathrm{q}_{\mathrm{e} \mu \mathrm{g}^{-1}}$ & $\mathrm{R}^{2}$ & $\mathrm{~K}_{\text {int } \min }{ }^{-1}$ & $\mathrm{C}$ & $\mathrm{R}^{2}$ \\
\hline $\mathrm{Pb}(\mathrm{II})$ & 0.809 & 1.08 & 2.88 & 0.917 & 0.74 & 0.96 & 0.981 & 0.461 & 0.421 & 0.905 \\
\hline $\mathrm{Co}(\mathrm{II})$ & 0.149 & 0.78 & 0.229 & 0.902 & 0.55 & 0.217 & 0.997 & 0.085 & 0.124 & 0.964 \\
\hline $\mathrm{Cd}(\mathrm{II})$ & 0.386 & 0.67 & 0.516 & 0.936 & 1.33 & 0.483 & 0.98 & 0.461 & 0.421 & 0.905 \\
\hline
\end{tabular}

Kinetic Parameter of the Adsorption of $\mathrm{Pb}$ (II), Cd(II), and $\mathrm{Co}$ (II) Using MCNDs as Adsorbent 
the adsorption studies were carried out at different temperatures ranging from $293 \mathrm{~K}$ to $373 \mathrm{~K}$. The following equations were used to calculate the various parameters of the thermodynamic studies for this particular adsorption study $(45,46)$ :

$$
\begin{aligned}
& \Delta G^{0}=-R T \ln K_{D} \\
& \Delta H^{0}=R \frac{T_{2} T_{1}}{T_{2}-T_{1}} \ln \frac{K_{2}}{K_{1}} \\
& \Delta S^{0}=\frac{\Delta H^{0}-\Delta G^{0}}{T}
\end{aligned}
$$

where $\mathrm{K}_{\mathrm{D}}$ is the equilibrium constant, $\mathrm{q}_{\mathrm{e}}$ equilibrium concentration of the metal ion on the adsorbent ( $\mathrm{mg} \mathrm{L}^{-1}$ ), and Ce is the concentration of the metal ion in the solution $\left(\mathrm{mg} \mathrm{L}^{-1}\right)$, respectively. The values of
$\left(\Delta S^{\circ}\right),\left(\Delta H^{\circ}\right)$, and $\left(\Delta G^{\circ}\right)$ were calculated, and the values are listed in the Table V. The negative values of all of these parameters show that this adsorption process is exothermic and highly feasible in nature.

\section{Analytical Performance of Method}

An analytical method can be performed by calculating various analytical parameters such as detection limit (LOD), limit of quantification (LOQ), enhancement factor (EF), preconcentration factor (PF), percent relative standard deviation, and correlation coefficient. All of these parameters were calculated as follows: The values of LOD were calculated as the ratio of three times standard deviation of 10 blank absorbances to the slope of the regression equation, while the values of the LOQ were calculated as 10 times the standard deviation of 10 blank absorbances to the slope of the regression equation. The percent relative standard deviation of three repeated determinations having 2 ppm concentrations was determined and given in the Table VI. EF was calculated by using the ratio of the slops with and without the preconcentration step (47). PF was calculated as the ratio of the model solution to the final volume and CIn is calculated as the ratio of sample volume (in milliliters) to enhancement factor. The values of these parameters are given in the Table VI.

\begin{tabular}{|c|c|c|c|c|c|c|c|c|c|}
\hline Temp. & $\begin{array}{c}\Delta \mathrm{G}^{\mathrm{o}} \\
\mathrm{KJmol}^{-1}\end{array}$ & $\begin{array}{c}\mathrm{Pb}(\mathrm{II}) \\
\Delta \mathrm{H}^{\mathrm{o}} \\
\mathrm{KJmol}^{-1}\end{array}$ & $\begin{array}{c}\Delta S^{\circ} \\
\mathrm{KJmol}^{-1}\end{array}$ & $\begin{array}{c}\Delta \mathrm{G}^{\mathrm{o}} \\
\mathrm{KJmol}^{-1}\end{array}$ & $\begin{array}{l}\mathrm{Cd}(\mathrm{II}) \\
\Delta \mathrm{H}^{\circ} \\
\mathrm{KJmol}^{-1}\end{array}$ & $\begin{array}{c}\Delta S^{\circ} \\
\mathrm{KJmol}^{-1}\end{array}$ & $\begin{array}{c}\Delta \mathrm{G}^{\mathrm{o}} \\
\mathrm{KJmol}^{-1}\end{array}$ & $\begin{array}{c}\mathrm{Co}(\mathrm{II}) \\
\Delta \mathrm{H}^{\mathrm{o}} \\
\mathrm{KJmol}^{-1}\end{array}$ & $\begin{array}{l}\Delta S^{\circ} \\
\mathrm{KJmol}^{-1}\end{array}$ \\
\hline 293 & -18.26 & & & -221.69 & & & -213.80 & & \\
\hline 303 & -15.42 & & & -189.24 & & & -182.66 & & \\
\hline 313 & -14.93 & & & -174.85 & & & -174.98 & & \\
\hline 323 & -14.27 & & & -172.11 & & & -158.37 & & \\
\hline 333 & -14.19 & -38.3 & -0.07 & -164.99 & -42.7 & -0.08 & -151.17 & -45.5 & 0.09 \\
\hline 343 & -12.87 & & & -158.19 & & & -148.94 & & \\
\hline 353 & -12.34 & & & -157.01 & & & -146.13 & & \\
\hline 363 & -11.99 & & & -155.39 & & & -137.54 & & \\
\hline 373 & -12.18 & & & -153.92 & & & -141.78 & & \\
\hline
\end{tabular}

TABLE V

Thermodynamics of Proposed Method for Adsorption of Pb(II), Cd(II), and Co(II) on magnetic carboxyl modified nanodiamonds MCNDs

TABLE VI

Analytical Parameters of Method

\begin{tabular}{lccc}
\hline Analytical Parameter & $\mathrm{Pb}(\mathrm{II})$ & $\mathrm{Cd}(\mathrm{II})$ & $\mathrm{Co}(\mathrm{II})$ \\
\hline Limit of detection $\left(\mu \mathrm{g} \mathrm{L}^{-1}\right)$ & 0.99 & 0.15 & 1.73 \\
Limit of quantification $\left(\mu \mathrm{g} \mathrm{L}^{-1}\right)$ & 3.3 & 4.95 & 5.8 \\
Preconcentration factor $(\mathrm{PF})$ & 20 & 20 & 20 \\
Enhancement factor $(\mathrm{EF})$ & 19.9 & 19 & 19 \\
Relative standard deviation $(\%)$ & 0.5 & 0.6 & 0.7 \\
Correlation coefficient $\left(\mathrm{r}^{2}\right)$ & 0.997 & 0.998 & 0.993 \\
\hline
\end{tabular}




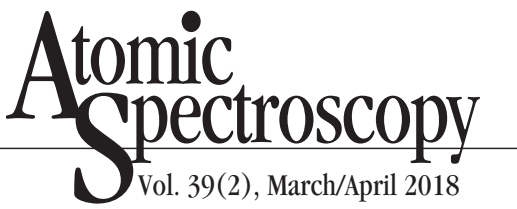

TABLE VII

Validation of Proposed Solid Phase Extraction Method of Pb(II), Cd(II), and Co(II) at Trace Level Using Certified Water Reference Material (pH: 7, Adsorbent: 0.1 g, Sample Volume: 15 mL, Final Volume: $2 \mathrm{~mL}$ )

\begin{tabular}{lcccccccccc}
\hline \multirow{2}{*}{ CRM } & \multicolumn{3}{c}{ Pb(II) } & \multicolumn{4}{c}{ Cd(II) } & \multicolumn{3}{c}{ Co(II) } \\
\hline TMDA 64.2 & 286 & $278 \pm 5^{\mathrm{a}}$ & 98 & 264 & $263 \pm 10$ & 99 & 253 & $257 \pm 12$ & 101 \\
SPS-WW2 & 500 & $479 \pm 20$ & 95 & 100 & $99 \pm 6$ & 99 & 300 & $295 \pm 13$ & 98 \\
\hline
\end{tabular}

${ }^{a}$ Mean of three determinations \pm standard deviation.

${ }^{\mathrm{b}}(\%)$ Recovery $=($ Observed Value/Expected Value $) \times 100$.

TABLE VIII

Addition Recovery Results for Pb(II), Cd(II), and Co(II) Using Proposed Solid Phase Extraction Method (pH: 7, Adsorbent: $0.1 \mathrm{~g}$, Sample Volume: $15 \mathrm{~mL}$, Final Volume: $2 \mathrm{~mL}$ $(\mathrm{N}=3)$

\begin{tabular}{llllllll}
\hline Sample & $\begin{array}{c}\text { Added } \\
(\mu \mathrm{g})\end{array}$ & $\begin{array}{c}\text { Found Recovery } \\
(\mu \mathrm{g})\end{array}$ & $\begin{array}{c}\text { Found } \\
(\%\end{array}$ & $\begin{array}{c}\mathrm{Cd}(\mathrm{II}) \\
(\mu \mathrm{g})\end{array}$ & $\begin{array}{c}\mathrm{C} \text { Co(II) } \\
(\%)\end{array}$ & $\begin{array}{c}\text { Found } \\
(\mu \mathrm{g})\end{array}$ & $\begin{array}{c}\text { Recovery } \\
(\%)\end{array}$ \\
\hline Underground & & & & & & & \\
Water & 0 & $\mathrm{BDL}^{\mathrm{a}}$ & - & 0.04 & - & 0.03 & - \\
& 0.5 & 0.94 & 94 & 0.29 & 100 & 0.53 & 100 \\
& 1 & 1.87 & 94 & 0.52 & 94 & 1.02 & 99 \\
Seawater & 0 & 0.11 & - & 0.07 & - & 0.10 & - \\
& 0.5 & 0.36 & 95 & 0.38 & 101 & 0.58 & 97 \\
& 1 & 0.63 & 103 & 0.41 & 96 & 1.09 & 99 \\
Wastewater & 0 & 0.09 & - & 0.06 & - & 0.06 & - \\
& 0.5 & 0.57 & 97 & 0.44 & 95 & 0.55 & 97 \\
& 1 & 1.07 & 98 & 0.49 & 95 & 1.07 & 101 \\
\hline
\end{tabular}

${ }^{\mathrm{a}} \mathrm{BDL}=$ Below the detection limit.

\section{Validation of the Method}

For trace metal analysis, two certified reference materials TMDA 64.2 Environmental Water and SPSWW2 Wastewater were used and the recovery results are listed in the Table VII. The quantitative recovery result shows that the method can successfully be used for trace metal analysis.

For addition recovery, the method was applied to underground water, seawater, and wastewater. The percent recovery results are given in Table VIII and show that the method is applicable to environmental water samples. The application of trace metal analysis and addition recovery shows that the proposed solid phase extrac- tion is highly accurate and valid for the determination of the toxic heavy metals.

The proposed solid phase extraction was compared with other extraction methods in the literature with regard to the LOD values (Table IX). It can be concluded that the developed method is either superior or similar in extraction efficiency to other extraction studies given in the literature (52-59).

\section{CONCLUSION}

Magnetic carboxyl modified nanodiamonds were synthesized and characterized. The adsorbent was used as magnetic solid phase extractant of $\mathrm{Pb}(\mathrm{II}), \mathrm{Cd}(\mathrm{II})$, and
Co(II) prior to the determination by FAAS. The $\mathrm{pH}$ of 7.0 was optimum to obtain maximum percent recoveries. The kinetic data fit to pseudofirst order kinetics. The thermodynamic data show that adsorption of $\mathrm{Pb}$ (II), $\mathrm{Cd}$ (II) and $\mathrm{Co}(\mathrm{II})$ on magnetic carboxyl nanodiamonds is feasible and exothermic in nature. The developed method is sensitive with low values of detection limits, reproducible with low values of RSD, and useful with other analytical techniques such as ICP-MS with the added benefit of matrix removal. The method was also successfully applied to certified reference materials and natural water samples.

\section{ACKNOWLEDGMENT}

Dr. Mansoor Khan is thankful to the Scientific and Technological Research Council of Turkey (TUBITAK) under the " 2216 Research Fellowship Programme for Foreign Citizens" for financial support.

Received May 15, 2017.

\section{REFERENCES}

1. S. Ogut, H.S. Canbay, and H. Uludag, Akademik Gida 14, 105 (2016).

2. L. Zhu, L. Xu, B. Huang, N. Jia, L. Tan, and S. Yao, Electrochim. Acta 115, 471 (2014).

3. H. Altundag, S. Doganci, M.S. Dundar, and E. Altintig, Fresen. Environ. Bull. 25, 2764 (2016). 
TABLE IX

Comparison of Developed Method With Other Pre-concentration Methods for Pb(II), Cd(II), and Co(II)

\begin{tabular}{|c|c|c|c|c|c|}
\hline Method & Analysis & $\mathrm{PF} / \mathrm{EF}$ & Detection Limit $\left(\mu \mathrm{g} \mathrm{L}^{-1}\right)$ & Sample & Reference \\
\hline Solid phase extraction & Flame AAS & 80 & $\mathrm{~Pb}$ (II): $0.6, \mathrm{Co}$ (II): 0.4 & Environment & (19) \\
\hline Solid phase extraction & Flame AAS & 200 & $\mathrm{~Pb}(\mathrm{II}): 1.1$ & Water & $(48)$ \\
\hline Solid phase extraction & FlameAAS & - & $\mathrm{Pb}(\mathrm{II}): 3.9, \mathrm{Co}(\mathrm{II}): 2.9$ & Environment & $(49)$ \\
\hline Solid phase extraction & Flame AAS & 100 & Pb: 0.86 & Hair & $(50)$ \\
\hline $\begin{array}{l}\text { Dispersive liquid- } \\
\text { liquid extraction }\end{array}$ & $\begin{array}{l}\text { X-Ray fluoresc. } \\
\text { spectrometry }\end{array}$ & - & $\mathrm{Pb}$ (II): $2.6, \mathrm{Co}(\mathrm{II}): 0.7$ & Water & (51) \\
\hline $\begin{array}{l}\text { Ionic liquid dispersive } \\
\text { liquid-liquid extraction }\end{array}$ & Flame AAS & - & $\mathrm{Pb}(\mathrm{II}): 9.5$ & Environment & $(52)$ \\
\hline $\begin{array}{l}\text { Dispersive liquid-liquid } \\
\text { extraction }\end{array}$ & GFAAS & 101 & Co(II): 0.03 & Rice and water & $(53)$ \\
\hline Solid phase extraction & Flame AAS & 20 & $\begin{array}{l}\mathrm{Pb}(\mathrm{II}): 0.99, \mathrm{Co}(\mathrm{II}): \\
1.73 \text {, Cd:0.148 }\end{array}$ & Water & This work \\
\hline
\end{tabular}

4. M. Gulfen, and A. Ozdemir, Nut. Food Sci. 46, 282 (2016).

5. M.W. Ashraf, Fresen. Environ. Bull 26, 4946 (2017)

6. Y. Adali, Koca, andY. Basimoglu, J. Environ. Prot. Ecol. 17, 477 (2016).

7. M. Soylak, and N.D. Erdogan, J. Hazard. Mater. 137, 1035 (2006)

8. I. Narin, and M. Soylak, Talanta 60 , 215 (2003) 215.

9. M. Mirzaei, M. Behzadi, N.M. Abadi, and A. Beizaei, J. Hazard. Mater. 186, 1739 (2011).

10. L. Moens, T. De Smaele, R. Dams, P. Van Den Broeck, and P. Sandra, Anal. Chem. 69, 1604 (1997).

11. N. Polat, and T. Akkan, Fresen. Environ. Bull. 25, 2884 (2016)

12. S. Mahpishanian, and F. Shemirani, Talanta 82, 471 (2010)

13. L. Ranjbar, Y. Yamini, A. Saleh, S. Seidi, and M. Faraji, Microchim. Acta 177, 119 (2012).

14. D.P. Laxen, and E.R. Sholkovitz, Environ. Technol. 2, 561 (1981).

15. E. Yilmaz, and M. Soylak, Anal. Chim. Acta, 886, 75 (2015).

16. C. Huang, and B. Hu, Spectrochim. Acta 63B, 437 (2008)

17. H.I. Ulusoy, Coll. Surf. 513A, 110 (2017).

18. G. Cheng, M. He, H. Peng, and B. Hu, Talanta 88, 507 (2012).
19. Z.A. ALOthman, M. Habila, E. Yilmaz, and M. Soylak, Microchim. Acta, 177, 397 (2012).

20. Y. Zhai, Q. He, X. Yang, and Q Han, Microchim. Acta, 169, 353 (2010).

21. N. Zhang, H. Peng, S. Wang, and B. $\mathrm{Hu}$, Microchim. Acta 175, 121 (2011).

22. M. Khan, E. Yilmaz, B. Sevinc, E. Sahmetlioglu, J. Shah, M.R. Jan, and M. Soylak, Talanta 146, 130 (2016).

23. J. Shah, M.R. Jan, M. Khan, and S. Amir, Desalin. Water Treat. 57, 9736 (2015).

24. D. Pérez-Quintanilla, A. Sánchez, I. del Hierr, M. Fajardo, and I. Sierra, Microchim. Acta 165, 291 (2009).

25. J.S. Suleiman, B. Hu, H. Peng, and C. Huang, Talanta 77, 1579 (2009).

26. Y. Liu, H. Li, and J.-M. Lin, Talanta, 77, 1037 (2009).

27. J. Li, X. Zhao, Y. Shi, S. Cai, G. Mou, and G. Jiang, J. Chromatogr. 1180A, 24 (2008).

28. G. Cicala, A. Massaro, L. Velardi, G.S. Senesi, and A. Valentini, ACS Appl. Mater. Interface, 6, 21101 (2014).

29. A. Krueger, Chem. Eur. J. 14, 1382 (2008).

30. E. Yilmaz, and M. Soylak, Talanta, 158, 152 (2016).
31. I. Narin, M. Soylak, K. Kayakirilmaz, L. Elci, and M. Dogan, Anal. Lett. 35, 1437 (2002).

32. M.H. Beyki, F. Feizi, and F. Shemirani, React. Funct. Poly. 103, 81 (2016).

33. E. Sancaktar, M. Bakan, I-T. Chang, S. Satam, and R. Farahati, Poly. Test. 56, 185 (2016).

34. K.-C. Hsu, C.-F. Lee, Y.-Y. Chao, C.C. Hung, P.-C. Chen, C.-H. Chiang, and Y.-L. Huang, J. Anal. At. Spectrom. 31, 2338 (2016).

35. V. Eyupoglu, H.I. Turgut, E. Polat, A. Kunduracioglu, M.E. Koc, Z. Sener, and R.A. Kumbasar, J. Dispersion Sci. Technol. 38, 110 (2017).

36. S.D. Zor, B. Asci, O.A. Dönmez, and D.Y. Kucukkaraca, J. Chromatogr. Sci. 54, 952 (2016).

37. M. Tuzen, and M. Soylak, J Hazard. Mater. 162, 724 (2009).

38. A. Larki, Spectrochim. Acta, 173A, 1 (2017).

39. M. Soylak, Y.E. Unsal, E. Yilmaz, and M. Tuzen, Food Chem. Toxicol. 49, 1796 (2011).

40. M. Soylak, and E. Yilmaz, Desalination 275, 297 (2011).

41. K. Pyrzyńska, and M. Bystrzejewski, Colloid Surface 362A, 102 (2010).

42. M. Soylak, Y.E. Unsal, N. Kizil, and A. Aydin, Food Chem. Toxicol. 48 m517 (2010) 


\section{Atomic $_{\text {Spectroscopy }}^{\text {to }}$ \\ $\bigcirc$ Vol. 39(2), March/April 2018}

43. M.S. Gasser, G.A. Morad, and H.F. Aly, J. Hazard. Mater. 142, 118 (2007).

44. S. Yadav, V. Srivastava, S. Banerjee, C.-H. Weng, and Y.C. Sharma, Catena 100, 120 (2013).

45. W. Konicki, I. Pełech, E. Mijowska, and I. Jasińska, Chem. Eng. J. 210, 87 (2012).

46. V.K. Gupta, C. Jain, I. Ali, M. Sharma, and V. Saini, Water Res. 37, 4038 (2003).

47. E. Yilmaz, and M. Soylak, Talanta, 116, 882 (2013).

48. E. Sahmetlioglu, E. Yilmaz, E. Aktas, and M. Soylak, Talanta 119, 447 (2014).

49. M. Tuzen, K.O. Saygi, C. Usta, and M. Soylak, Bioresour. Technol. 99, 1563 (2008).

50. N. Jalbani, and M. Soylak, Int. J. Environ. An. Ch. 94, 1435 (2014).

51. K. Kocot, and B. Zawisza, R. Sitko, Spectrochim. Acta 73B, 79 (2012).

52. H. Bai, Q. Zhou, G. Xie, and J. Xiao, Talanta 80, 1638 (2010).

53. H. Jiang, Y. Qin, and B. Hu, Talanta, 74, 1160 (2008)

54. M. Soylak, L. Elci, and M. Dogan, Anal. Lett. 26, 1997 (1993).

55. F. Ge, M.-M Li, H. Ye, and B-X. Zhao, J. Hazard. Mater. 211, 366 (2012).

56. M. Sheibani, F. Marahel, M. Ghaedi, M. Montazerozohori, and M. Soylak, Toxicol. Environ. Chem. 93, 862 (2011).

57. U. Divrikli, A.A. Kartal, M. Soylak, and L. Elci, J. Hazard. Mater. 145, 459 (2007).

58. A. Elik, N. Altunay, and R. Gürkan, J. Mol. Liq. 247, 262 (2017).

59. D. Ozdes, A. Gundogdu, B. Kemer, C. Duran, H.B. Senturk, and M. Soylak, J. Hazard. Mater. 166, 1480 (2009). 